\title{
Bioactive Components of Pandan's Fruits from Jayawijaya Mountains, Papua, Indonesia
}

\author{
Been Kogoya ${ }^{1)}$, Bambang Guritno ${ }^{2)}$ Ariffin $^{2)}$ and Agus Suryanto ${ }^{2)}$ \\ ' (Graduate School of Agriculture, Department of Agriculture, University of Brawijaya, Malang, East Java, \\ Indonesia) \\ ${ }^{2}$ (Department of Agriculture, University of Brawijaya, Malang, East Java, Indonesia)
}

\begin{abstract}
Five Pandan species, namely Pandanus julianettii, Pandanus iwen, Pandanus brosimos, Pandanus sp.1 (owadak) and Pandanus sp.2 (woromo) from Jaya Wijaya Mountains, Papua have potential bioactive components. This study aimed to identify the bioactive components in Pandan's fleshy receptacle and seed from five Pandan species. Samples were obtained from fleshy receptacle and seed. Sample were mashed and dried for further proximate, minerals, and vitamins contents analysis. The study revealed that nutritive value compositions of food fiber per 100 grams in fleshy receptacle and seed of Pandanus julianettii were $23 \%$ and $12 \%$; those of Pandanus sp. 1 (owadak) were $17.59 \%$ and $18.38 \%$; those of Pandanus sp. 2 (woromo) were $30 \%$ and $23 \%$; those of Pandanus iwen were $18 \%$ and $30 \%$; those of Pandanus brosimos were $47.75 \%$ and $17.40 \%$. The nutritive value compositions of starch per 100 grams in pandan's fleshy receptacle and seed of Pandanus julianettii were $23 \mathrm{ppm}$ and $0.24 \mathrm{ppm}$; those of Pandanus sp. 1 (owadak) were $26 \mathrm{ppm}$ and $0.96 \mathrm{ppm}$; those of Pandanus sp.2 (woromo) were $36 \mathrm{ppm}$ and $18 \mathrm{ppm}$; those of Pandanus iwen were $21 \mathrm{ppm}$ and $0.21 \mathrm{ppm}$; those of Pandanus brosimos were $35.88 \mathrm{ppm}$ and $9.67 \mathrm{ppm}$. The nutritive value compositions of vitamin C per 100 grams in fleshy receptacle and seed of Pandanus julianettii were $8.10 \mathrm{mg}$ and $6.40 \mathrm{mg}$; those of Pandanus sp.1 (owadak) were $16.88 \mathrm{mg}$ and $9.74 \mathrm{mg}$; those of Pandanus sp.2 (woromo) were $20 \mathrm{mg}$ and $1.72 \mathrm{mg}$; those of Pandanus iwen were $10 \mathrm{mg}$ and $4 \mathrm{mg}$; those of Pandanus brosimos were $185.68 \mathrm{mg}$ and $109.84 \mathrm{mg}$. The nutritive value compositions of vitamin E per $100 \mathrm{~g}$ in fleshy receptacle and seed of Pandanus julianettii were $0.19 \mathrm{mg}$ and $0.46 \mathrm{mg}$; those of Pandanus sp.1 (owadak) were $3.18 \mathrm{mg}$ and $15 \mathrm{mg}$; those of Pandanus sp.2 (woromo) were $6 \mathrm{mg}$ and $0.07 \mathrm{mg}$; those of Pandanus iwen were $0.19 \mathrm{mg}$ and $8 \mathrm{mg}$; those of Pandanus brosimos were $185.68 \mathrm{mg}$ and $109.84 \mathrm{mg}$.
\end{abstract}

Keywords: Pandan, medicinal herbs, Papua biodiversity, conservation

\section{Introduction}

Mountain ecosystem in tropical countries is home of myriad biodiversity [1]. The middle mountain area of Jayawijaya is a rich region for Pandanaceae. The Pandanus genus is tropical fruits which are found 17503500 asl. There have been more than seven species of Pandan cultivated in forests. Pandans fruits have been used as an alternative carbohydrate source by local residents in the middle mountain area of Jayawijaya, including P. julianettii, P. iwen, P. brosimos, Pandanus sp1. (owadak), Pandanus sp2. (woromo), P. antaresensis and $P$. conoideus. The center areas of Pandans fruit production in the middle mountain area of Jayawijaya are Regencies of Puncak Jaya, Puncak Ilaga, Tolikara, Lanny Jaya, Puncak Trikora, Nduga, Wamena, Central Mambramo, Yahukimo, Yalimo, Mts. Bintang and Papua New Guinea. The flowering season is between November-August. In Papua, Pandan's fleshy receptacle and seed are directly consumed in the form of fresh or dry fruits. Seeds have hard shell coat, resist up to two years, and are able to be dried [2] [3] [4] [5].

Scholars point out that $P$. brosimos and $P$. julianettii fruits have significant roles in people life in the mountainous area of Papua New Guinea (PNG) as food-stuff, traditional medicine, and ritual materials[2] [4]. Purwanto and Munawaroh (2010) confirmed that $P$. julianettii, $P$. brosimos and $P$. iwen were used as medicine materials among Dani tribe in Wamena [6]. Pandan fruit have economical value. They are traditionally treated as food source and medicine by people of East area in Indonesia and Papua New Guinea [3] [4] [7].

Fulfilling adequate food, both in quantity and quality, securely, well-distributed and affordable by all households are the main objective in economic development. Demands of food and medicine increase along with the population growth which promotes the acceleration of food production in order to achieve price stability and food availability. Thus, food security in local context is highly related to the government ability in order to keep the stability of local food availability [8] [9]. In such a case, Pandan fruits have a great potency in food security program. The significance of local food security as the vehicle to reinforce economic stability, health and politics, and food availability with affordable and promising price are main reasons to cultivate Pandan.

Fruits of Pandan plant are potential as food-stuffs and medicine. However, the information on nutrition and medical potency of its fruits has not yet revealed. The study aimed to identify the potency of fruit's nutritive 
value on proximate, minerals, and vitamins in Pandan's fleshy receptacle and seed and provided the precise information to develop into food and medicine from five species of Pandans.

\section{Materials and methods}

Mature Pandan's fleshy receptacle and seed fruits samples were collected from different sites. Samples of fruit were directly taken from the field under the criteria in which fruits were already ripe. Pandan fruits have two key components-fleshy receptacle and seed. Fruits were picked from trees and peeled from the skin. The fleshy receptacle and seed were separated and dried directly under the sun exposure for five weeks.

Endosperms were derived from seed by breaking the seed coat. White endosperm contains insoluble dietary fiber which has cellulose, hemicelluloses and lignin fibers. Meanwhile, the fleshy receptacle has various fruit color depending on the species of Pandan, i.e.is white, yellow, and orange. Pandans contains dietary fiber such as cellulose, hemicelluloses, pectin substance, and insoluble glycoprotein.

Dry flesy receptacle and endosperm were mashed by wood pestle and mortar. The mashed result could be filtered by 80 mesh flour sieve, and packaged in plastics. Fleshy receptacle and endosperm from each Pandan plant were labeled for the content analysis of further bioactive materials.

Collecting samples was based on SNI (Indonesian National Standard) 19-0428-1989 for solid material. The water content was measured under standard methods of SNI 01-2891-1992 point 5.1; ash content was measured under standard methods of SNI 01-2891-1992 point 6.1); proteins were measured under standard methods of SNI 01-2891-1992 point 7.1); lipids were measured under standard methods of SNI 01-2891-1992 point 8.2, carbohydrates were measured under standard methods of SNI 01-2891-1992 point 9; calories (IK A2-06), saturated fat, trans fat, cholesterol were measured by Gases Chromatographic (GC). The fiber was evaluated under gravimetric methods of AOAC 985.29 (18th Ed., 2005). The total sugar was measured under SNI 01-2891-1992, point 4.1. Sodium (Na), Potassium (K) and Calcium (Ca) in fleshy receptacle and seed were evaluated by AAS based on the method of AOAC 985.35. Iron (Fe) was measured under standard methods of SNI 3751: 2009 point A.10 (AAS). Vitamin A, E, and Beta carotene in pandan's fleshy receptacle and seed were analyzed by High Performance Liquid Chromatography (HPLC). Vitamin C was analyzed by AOAC 967.21 (1993) methods.

The Butyric acid (C4:0), Caproic acid (C6:0), Capric acid (C8:0), Undecanoic acid (C11:0), Lauric acid (C12:0), Tridecanoic acid (C13:0), Myristic acid (C14:0), Myristoleic acid (C14:1), Pentadecanoic acid (15:0), Pentadecanoic acid (15:1). Palmitic acid (C16:0), Palmitoleic acid (C16:1), Heptadecanoic acid (17:0), Heptadecanoic acid (17:1), Stearic acid (C18:0), Stearic acid (C18:0), Oleic acid (C18:1) [trans-9], Oleic acid (C18:1) [cis-9], Linoleic acid(C18:2)[trans-9], Linoleic acid(C18:2)[cis-9], Arachidic acid (C20:0), Linolenic acid (C18:3)[cis-6], Eicosenoic acid (20:1), Linolenic acid (C18:3)[cis-9], Heneicosanoic acid (C20:2), Eicosadienoic acid (20:2), Behenic acid (C22:1), Eicosatrienoic acid (20:3)[cis-8], Eicosatrienoic acid (20:3)[cis-11], Arachidonic acid (C20:4), Erucic acid (C22:1), Tricosanoic acid (23:0), Docosadienoic acid (C22:2), Eicosapentaenoic acid (C20:5) and Docosahexaenoic acid (C22:6) in Pandan seed were measured by High Performance Liquid Chromatography (HPLC).

\section{Results and Discussions}

\section{Nutritive Value of fleshy receptacle and seed}

Pandan is a plant with promising nutrition potency. The testing result of nutritive value composition in five species of Pandan could be observed from Table 1 as follows:

Table 1. Compositions of nnutritive values in five species of Pandan fruit per 100 grams in seed

\begin{tabular}{|l|l|c|c|c|c|c|}
\hline \multirow{2}{*}{ No } & Parameters & \multicolumn{3}{|c|}{ Composition } \\
\cline { 3 - 6 } & & $P$. julianettii & P. iwen & $\begin{array}{c}\text { P. sp1. } \\
\text { (owadak) }\end{array}$ & $\begin{array}{c}\text { P. sp.2 } \\
\text { (woromo) }\end{array}$ & P. brosimos \\
\hline 1 & Water content (\%) & 3.75 & 3.10 & 4.64 & 7.48 & 4.78 \\
\hline 2 & Ash content (\%) & 4.22 & 3.81 & 3.97 & 3.84 & 5.88 \\
\hline 3 & Protein (\%) & 18 & 15.08 & 10.41 & 15.40 & 16.06 \\
\hline 4 & Total fat (\%) & 47 & 50 & 33.08 & 48.46 & 48.41 \\
\hline 5 & Energy from fat kcal & 420 & 450 & 300 & 440 & 485 \\
\hline 6 & Total Energy kcal & 1020 & 1070 & 530 & 1040 & 1607 \\
\hline 7 & Carbohydrate (\%) & 28 & 27.61 & 47.90 & 25 & 20.06 \\
\hline 8 & Fat calories kcal/100 g & 419.40 & 450 & 264.11 & 346.14 & 410.07 \\
\hline 9 & Saturated fatty acid (\%) & 18 & 3 & 1.65 & 1.5 & 1.74 \\
\hline 10 & Unsaturated fatty acid (\%) & 401.4 & 497 & 317,9 & 438.5 & 413.4 \\
\hline 11 & Trans fatty acid (ppm) & 0 & 0 & 0 & 0 & 0 \\
\hline 12 & Cholesterol (\%) & 0 & 0 & 7 & 0 & 0 \\
\hline 13 & Dietary fiber (\%) & 12 & 30 & 18.38 & 23 & 17.40 \\
\hline 14 & Total sugar (\%) & 5 & 2 & 3.12 & 4 \\
\hline 15 & Betacaroten (ppm) & 8.42 & 4.11 & 2.24 & 4.4 & 0.44 \\
\hline
\end{tabular}


Bioactive Components of Pandan's Fruits from Jaya Wijaya Mountains, Papua, Indonesia

\begin{tabular}{|l|l|c|c|l|c|l|}
\hline 16 & Starch $(\mathrm{ppm})$ & 0.24 & 0.21 & 0.96 & 18 & 9.67 \\
\hline 17 & Sodium $(\mathrm{mg} / 100 \mathrm{~g})$ & 71.21 & 56.25 & 22.49 & 77.58 & 68.36 \\
\hline 18 & Potassium $(\mathrm{mg} / 100 \mathrm{~g})$ & 300.22 & 255.2 & 123.05 & 246.60 & 117.84 \\
\hline 19 & Calcium $(\mathrm{mg} / 100 \mathrm{~g})$ & 97.20 & 51.44 & 2.46 & 72.44 & 92.95 \\
\hline 20 & Iron $(\mathrm{mg} / 100 \mathrm{~g})$ & 0.45 & 0.32 & 0.31 & 0.37 & 13.52 \\
\hline 21 & Vitamin A (IU/g) & 0.02 & 0.02 & 864.84 & 0.02 & 0.76 \\
\hline 22 & Vitamin C (mg/100 g) & 6.40 & 4 & 9.74 & 1.72 & 109.84 \\
\hline 23 & Vitamin E (mg/100 g) & 0.46 & 8 & 15 & 0.07 & 17 \\
\hline
\end{tabular}

The result of testing the composition of nutritive value in fleshy receptacle of five Pandan species could be studied in Table 2 as follows:

Table 2. Nutritive values in five species of Pandan fruit per 100 grams in fleshy receptacle

\begin{tabular}{|c|c|c|c|c|c|c|}
\hline \multirow[t]{2}{*}{ No } & \multirow[t]{2}{*}{ Parameters } & \multicolumn{5}{|c|}{ Composition } \\
\hline & & P. julianettii & P. iwen & $\begin{array}{c}P . s p 1 . \\
\text { (owadak) }\end{array}$ & $\begin{array}{c}P . \mathrm{sp} .2 \\
\text { (woromo) }\end{array}$ & P. brosimos \\
\hline 1 & Water content $(\%)$ & 10.93 & 12.68 & 5.98 & 10.20 & 11.21 \\
\hline 2 & Ash content $(\%)$ & 3.41 & 3.88 & 3.88 & 4.82 & 4.26 \\
\hline 3 & Protein $(\%)$ & 8.00 & 5.84 & 7.29 & 10 & 5.74 \\
\hline 4 & Total fat $(\%)$ & 0.67 & 0.43 & 20.58 & 1 & 1.34 \\
\hline 5 & Total energy kcal & 350 & 340 & 450 & 340 & 11, \\
\hline 6 & Carbohydrate (\%) & 77 & 77.17 & 62.27 & 74 & 77.45 \\
\hline 7 & Fat calory kcal/100 g & 6.03 & 3.87 & 185.22 & 8.46 & 3590.80 \\
\hline 8 & Saturated fatty acid (\%) & 0 & 0 & 12 & 0 & 1.63 \\
\hline 9 & Unsaturated fatty acid (\%) & 0.01 & 0 & 188.08 & 0.94 & 67.90 \\
\hline 10 & Trans fatty acid (ppm) & 0 & 0 & 0 & 0 & 0 \\
\hline 11 & Cholesterol (\%) & 0 & 0 & 0 & 0 & 0 \\
\hline 12 & Dietary fiber $(\%)$ & 23 & 18 & 17.59 & 30 & 47.75 \\
\hline 13 & Total sugar $(\%)$ & 11 & 6 & 5.86 & 5 & 3.86 \\
\hline 14 & Betakaroten (ppm) & 1.23 & 1.29 & 2.24 & 1.64 & 21.04 \\
\hline 15 & Starch (ppm) & 23 & 21 & 26 & 36 & 35.88 \\
\hline 16 & Sodium $(\mathrm{mg} / 100 \mathrm{~g})$ & 87.84 & 49.20 & 25.86 & 47.19 & 73.96 \\
\hline 17 & Potassium $(\mathrm{mg} / 100 \mathrm{~g})$ & 248.80 & 311.89 & 118.95 & 295.19 & 343.67 \\
\hline 18 & Calcium (mg / $100 \mathrm{~g})$ & 148.55 & 127.00 & 18.31 & 284.90 & 351.41 \\
\hline 19 & Iron $(\mathrm{mg} / 100 \mathrm{~g})$ & 0.42 & 0.28 & 0.31 & 0.30 & 17.74 \\
\hline 20 & Vitamin A (IU/g) & 0.02 & 0.02 & 279.21 & 0.02 & 0.87 \\
\hline 21 & Vitamin C (mg/100 g) & 8.10 & 10 & 16.88 & 20 & 185.68 \\
\hline 22 & Vitamin E (mg/100 g) & 0.19 & 0.19 & 3.18 & 6 & 2.97 \\
\hline
\end{tabular}

\section{Chemical Composition of Fatty Acid Group in Seeds}

The testing result of fatty acid type group in Pandanus julianettii, Pandanus sp.1 (owadak), Pandanus sp.2 (woromo), and Pandanus iwen seeds was listed in Table 3 as follows:

Table 3. Group of fatty acid type in four kinds of Pandan (in percent)

\begin{tabular}{|c|c|c|c|c|c|}
\hline No & Group of fatty acid type & P. julianettii & P.sp1. (owadak) & $\begin{array}{c}P . \text { sp.2 } \\
\text { (woromo) }\end{array}$ & P. iwen \\
\hline 1 & Butyric acid (C4:0) & 0.02 & 0.01 & 0.03 & 0.03 \\
\hline 2 & Caproic acid (C6:0) & 0.29 & 0.06 & 0.16 & 0.24 \\
\hline 3 & Capric acid (C8:0) & 0.34 & 0.20 & 0.19 & 0.30 \\
\hline 4 & Capric acid (C10:0) & 0.07 & 0.06 & 0.06 & 0.07 \\
\hline 5 & Undecanoic acid (C11:0) & 0.04 & 0.01 & 0.02 & 0.03 \\
\hline 6 & Lauric acid $(\mathrm{C} 12: 0)$ & 0.02 & 0.11 & 0.07 & 0.01 \\
\hline 7 & Tridecanoic acid (C13:0) & 0.01 & 0.02 & 0.01 & 0.01 \\
\hline 8 & Myristic acid (C14:0) & 0.07 & 0.08 & 0.07 & 0.09 \\
\hline 9 & Myristoleic acid (C14:1) & 0.00 & 0.00 & 0.00 & 0.00 \\
\hline 10 & Pentadecanoic acid (15:0) & 0.07 & 0.12 & 0.10 & 0.05 \\
\hline 11 & Pentadecanoic acid $(15: 1)$ & 0.00 & 0.00 & 0.00 & 0.01 \\
\hline 12 & Palmitic acid (C16:0) & 28.66 & 9.21 & 19.91 & 23.22 \\
\hline 13 & Palmitoleic acid (C16:1) & 0.01 & 0.16 & 0.06 & 0.01 \\
\hline 14 & Heptadecanoic acid (17:0) & 0.08 & 0.06 & 0.07 & 0.08 \\
\hline 15 & Heptadecanoic acid (17:1) & 0.01 & 0.04 & 0.02 & 0.02 \\
\hline 16 & Stearic acid $(\mathrm{C} 18: 0)$ & 3.77 & 0.74 & 2.57 & 3.80 \\
\hline 17 & Oleic acid (C18:1) [trans-9] & 1.84 & 0.02 & 0.00 & 0.77 \\
\hline 18 & Oleic acid (C18:1) [cis-9] & 9.29 & 12.20 & 10.17 & 17.42 \\
\hline 19 & Linoleic acid(C18:2)[trans-9] & 0.00 & 0.00 & 0.00 & 0.00 \\
\hline 20 & Linoleic acid(C18:2)[cis-9] & 0.33 & 0.11 & 0.04 & 1.39 \\
\hline 21 & Arachidic acid (C20:0) & 0.44 & 0.28 & 0.08 & 0.37 \\
\hline 22 & Linolenic acid (C18:3)[cis-6] & 0.00 & 0.02 & 0.03 & 0.00 \\
\hline
\end{tabular}


Bioactive Components of Pandan's Fruits from Jaya Wijaya Mountains, Papua, Indonesia

\begin{tabular}{|l|l|l|l|l|l|}
\hline 23 & Eicosenoic acid (20:1) & 0.02 & 0.17 & 0.23 & 0.01 \\
\hline 24 & Linolenic acid (C18:3)[cis-9] & 0.02 & 0.00 & 0.00 & 0.16 \\
\hline 25 & Heneicosanoic acid (C20:2) & 0.52 & 1.01 & 1.29 & 0.38 \\
\hline 26 & Eicosadienoic acid (20:2) & 0.70 & 0.20 & 0.22 & 0.52 \\
\hline 27 & Behenic acid (C22:1) & 0.00 & 0.05 & 0.03 & 0.01 \\
\hline 28 & Eicosatrienoic acid (20:3)[cis-8] & 0.14 & 0.09 & 0.05 & 0.13 \\
\hline 29 & Eicosatrienoic acid (20:3)[cis-11] & 0.12 & 0.04 & 0.03 & 0.10 \\
\hline 30 & Arachidonic acid (C20:4) & 0.00 & 0.00 & 0.00 & 0.00 \\
\hline 31 & Erucic acid (C22:1) & 0.00 & 0.00 & 0.00 & 0.00 \\
\hline 32 & Tricosanoic acid (23:0) & 0.03 & 0.03 & 0.03 & 0.02 \\
\hline 33 & Docosadienoic acid (C22:2) & 0.00 & 0.07 & 0.02 & 0.00 \\
\hline 34 & Eicosapentaenoic acid (C20:5) & 0.09 & 0.00 & 0.00 & 0.04 \\
\hline 35 & Docosahexaenoic acid (C22:6) & 0.00 & 0.02 & 0.01 & 0.00 \\
\hline
\end{tabular}

Based on the composition of nutritive values in Tables 1 and 2 above, the percent daily value (\% DV) could be calculated. The calculation was based on the attachment Decree of Head of Supervisory Board of Drugs and Foods of Republic of Indonesia Number: HK. 00.05.52.6291. The calculation result was listed in Tables 4, 5, 6 and 7:

Table 4. Calculation of Percent DV in pulp and seed of Pandanus julianettii

\begin{tabular}{|c|c|c|c|}
\hline \multicolumn{4}{|c|}{ Fleshy receptacle per 100 gram of Pandanus julianettii } \\
\hline No & Parameters & Composition of nutritive values & $\% \mathrm{DV}^{*}$ \\
\hline 1 & Total fat & $0,5 \mathrm{~g}$ & $1 \%$ \\
\hline 2 & Saturated fat & $0 \mathrm{~g}$ & $0 \%$ \\
\hline 3 & Trans fat & $0 \mathrm{~g}$ & \\
\hline 4 & Cholesterol & $0 \mathrm{mg}$ & $0 \%$ \\
\hline 5 & Protein & $8 \mathrm{~g}$ & $13 \%$ \\
\hline 6 & Total carbohydrate & $77 \mathrm{~g}$ & $26 \%$ \\
\hline 7 & Dietary fiber & $23 \mathrm{~g}$ & $92 \%$ \\
\hline 8 & Sugar & $11 \mathrm{~g}$ & \\
\hline 9 & Sodium & $90 \mathrm{~g}$ & $4 \%$ \\
\hline 10 & Potassium & 250 & $5 \%$ \\
\hline 11 & Vitamin A & & $0 \%$ \\
\hline 12 & Vitamin C & & $10 \%$ \\
\hline 13 & Vitamin E & & $0 \%$ \\
\hline 14 & Calcium & & $20 \%$ \\
\hline 15 & Iron & & $0 \%$ \\
\hline \multicolumn{4}{|c|}{ Seed per 100 grams of Pandanus julianettii } \\
\hline No & Parameters & Composition of nutritive values & $\% \mathrm{DV}^{*}$ \\
\hline 1 & Total fat & $47 \mathrm{~g}$ & $75 \%$ \\
\hline 2 & Saturated fat & $18 \mathrm{~g}$ & $100 \%$ \\
\hline 3 & Trans fat & $0 \mathrm{~g}$ & \\
\hline 4 & Cholesterol & $0 \mathrm{mg}$ & $0 \%$ \\
\hline 5 & Protein & $18 \mathrm{~g}$ & $29 \%$ \\
\hline 6 & Total carbohydrate & $28 \mathrm{~g}$ & $9 \%$ \\
\hline 7 & Dietary fiber & $25 \mathrm{~g}$ & $99 \%$ \\
\hline 8 & Sugar & $5 \mathrm{~g}$ & \\
\hline 9 & Sodium & $70 \mathrm{~g}$ & $3 \%$ \\
\hline 10 & Potassium & $300 \mathrm{~g}$ & $6 \%$ \\
\hline 11 & Vitamin A & & $0 \%$ \\
\hline 12 & Vitamin C & & $8 \%$ \\
\hline 13 & Vitamin E & & $4 \%$ \\
\hline 14 & Calcium & & $10 \%$ \\
\hline 15 & Iron & & $0 \%$ \\
\hline
\end{tabular}

*Percent Daily Values based on 2000 calorie diet.

Table 5. Calculation of Percent DV in pulp and seed of Pandanus iwen

\begin{tabular}{|clcc|}
\hline \multicolumn{2}{|c|}{ Fleshy receptacle per 100 grams of Pandanus iwen } & & \\
\hline No & Parameters & Composition of nutritive values & $\% \mathrm{DV}^{*}$ \\
\hline 1 & Total fat & $0,5 \mathrm{~g}$ & $1 \%$ \\
2 & Saturated fat & $0 \mathrm{~g}$ & $0 \%$ \\
3 & Trans fat & $0 \mathrm{~g}$ & $0 \%$ \\
4 & Cholesterol & $0 \mathrm{mg}$ & $10 \%$ \\
5 & Protein & $6 \mathrm{~g}$ & $26 \%$ \\
6 & Total carbohydrate & $77 \mathrm{~g}$ & $71 \%$ \\
7 & Dietary fiber & $18 \mathrm{~g}$ & $2 \%$ \\
8 & Sugar & $6 \mathrm{~g}$ & $7 \%$ \\
9 & Sodium & $50 \mathrm{mg}$ & $0 \%$ \\
10 & Potassium & $310 \mathrm{mg}$ & $10 \%$
\end{tabular}




\begin{tabular}{|c|c|c|c|}
\hline $\begin{array}{l}13 \\
14 \\
15 \\
\end{array}$ & $\begin{array}{l}\text { Vitamin E } \\
\text { Calcium } \\
\text { Iron }\end{array}$ & & $\begin{array}{c}0 \% \\
15 \% \\
0 \%\end{array}$ \\
\hline \multicolumn{4}{|c|}{ Seed per 100 grams of Pandanus iwen } \\
\hline No & Parameters & Composition of nutritive values & $\% \mathrm{DV}^{*}$ \\
\hline 1 & Total fat & $50 \mathrm{~g}$ & $81 \%$ \\
\hline 2 & Saturated fat & $3 \mathrm{~g}$ & $16 \%$ \\
\hline 3 & Trans fat & $0 \mathrm{~g}$ & \\
\hline 4 & Cholesterol & $0 \mathrm{mg}$ & $0 \%$ \\
\hline 5 & Protein & $15 \mathrm{~g}$ & $25 \%$ \\
\hline 6 & Total carbohydrate & $28 \mathrm{~g}$ & $9 \%$ \\
\hline 7 & Dietary fiber & $30 \mathrm{~g}$ & $120 \%$ \\
\hline 8 & Sugar & $2 \mathrm{~g}$ & \\
\hline 9 & Sodium & $55 \mathrm{~g}$ & $2 \%$ \\
\hline 10 & Potassium & $260 \mathrm{~g}$ & $5 \%$ \\
\hline 11 & Vitamin A & & $0 \%$ \\
\hline 12 & Vitamin C & & $4 \%$ \\
\hline 13 & Vitamin E & & $8 \%$ \\
\hline 14 & Calcium & & $6 \%$ \\
\hline 15 & Iron & & $0 \%$ \\
\hline
\end{tabular}

*Percent Daily Values based on 2000 calorie diet.

Table 6. Calculation of Percent DV in pulp and seed of Pandanus sp.2 (woromo)

\begin{tabular}{|c|c|c|c|}
\hline \multicolumn{4}{|c|}{ Fleshy receptacle per 100 grams of Pandanus sp.2 (woromo) } \\
\hline No & Parameters & Composition of nutritive values & $\% \mathrm{DV}^{*}$ \\
\hline 1 & Total fat & $1 \mathrm{~g}$ & $2 \%$ \\
\hline 2 & Saturated fat & $0 \mathrm{~g}$ & $0 \%$ \\
\hline 3 & Trans fat & $0 \mathrm{~g}$ & \\
\hline 4 & Cholesterol & $0 \mathrm{mg}$ & $0 \%$ \\
\hline 5 & Protein & $10 \mathrm{~g}$ & $16 \%$ \\
\hline 6 & Total carbohydrate & $74 \mathrm{~g}$ & $25 \%$ \\
\hline 7 & Dietary fiber & $30 \mathrm{~g}$ & $121 \%$ \\
\hline 8 & Sugar & $3 g$ & \\
\hline 9 & Sodium & $50 \mathrm{mg}$ & $2 \%$ \\
\hline 10 & Potassium & $300 \mathrm{mg}$ & $6 \%$ \\
\hline 11 & Vitamin A & & $0 \%$ \\
\hline 12 & Vitamin C & & $20 \%$ \\
\hline 13 & Vitamin E & & $6 \%$ \\
\hline 14 & Calcium & & $35 \%$ \\
\hline 15 & Iron & & $0 \%$ \\
\hline \multicolumn{4}{|c|}{ Seed per 100 grams of Pandanus sp.2 (woromo) } \\
\hline No & Parameters & Composition of nutritive values & $\% \mathrm{DV}^{*}$ \\
\hline 1 & Total fat & $48 \mathrm{~g}$ & $78 \%$ \\
\hline 2 & Saturated fat & $1,5 \mathrm{~g}$ & $9 \%$ \\
\hline 3 & Trans fat & $0 \mathrm{~g}$ & \\
\hline 4 & Cholesterol & $0 \mathrm{mg}$ & $0 \%$ \\
\hline 5 & Protein & $15 \mathrm{~g}$ & $26 \%$ \\
\hline 6 & Total carbohydrate & $25 \mathrm{~g}$ & $8 \%$ \\
\hline 7 & Dietary fiber & $23 \mathrm{~g}$ & $93 \%$ \\
\hline 8 & Sugar & $4 \mathrm{~g}$ & \\
\hline 9 & Sodium & $80 \mathrm{mg}$ & $3 \%$ \\
\hline 10 & Potassium & $250 \mathrm{mg}$ & $5 \%$ \\
\hline 11 & Vitamin A & & $0 \%$ \\
\hline 12 & Vitamin C & & $0 \%$ \\
\hline 13 & Vitamin E & & $0 \%$ \\
\hline 14 & Calcium & & $10 \%$ \\
\hline 15 & Iron & & $0 \%$ \\
\hline
\end{tabular}

*Percent Daily Values based on 2000 calorie diet.

Table 7. Calculation of Percent DV in fleshy receptacle and seed of Pandanus sp.1 (owadak)

\begin{tabular}{|clcc|}
\hline \multicolumn{1}{|c|}{ Fleshy receptacle per 100 grams } & & \\
\hline No & \multicolumn{1}{|c|}{ Parameters } & Composition of nutritive values & D DV $^{*}$ \\
\hline 1 & Total fat & $21 \mathrm{~g}$ & $33 \%$ \\
2 & Saturated fat & $12 \mathrm{~g}$ & $67 \%$ \\
3 & Trans fat & $0 \mathrm{~g}$ & $1 \%$ \\
4 & Cholesterol & $2 \mathrm{mg}$ & $12 \%$ \\
5 & Protein & $7 \mathrm{~g}$ & $21 \%$ \\
6 & Total carbohydrate & $62 \mathrm{~g}$ & $70 \%$ \\
7 & Dietary fiber & $18 \mathrm{~g}$ & $1 \%$ \\
8 & Sugar & $6 \mathrm{~g}$ & $3 \%$ \\
9 & Sodium & $25 \mathrm{~g}$ & $3 \%$ \\
10 & Potassium & $120 \mathrm{~g}$ & \\
\hline
\end{tabular}




\begin{tabular}{|clcc|}
\hline 11 & Vitamin A & & $15 \%$ \\
12 & Vitamin C & & $20 \%$ \\
13 & Vitamin E & & $20 \%$ \\
14 & Calcium & & $2 \%$ \\
15 & Iron & Composition of nutritive values & $0 \%$ \\
\hline Seed per 100 grams & $33 \mathrm{~g}$ & $\%$ DV* \\
\hline No & \multicolumn{1}{|c|}{ Parameters } & $25 \mathrm{~g}$ & $53 \%$ \\
\hline 1 & Total fat & $0 \mathrm{~g}$ & $137 \%$ \\
2 & Saturated fat & $20 \mathrm{mg}$ & $7 \%$ \\
3 & Trans fat & $10 \mathrm{~g}$ & $17 \%$ \\
4 & Cholesterol & $48 \mathrm{~g}$ & $16 \%$ \\
5 & Protein & $18 \mathrm{~g}$ & $74 \%$ \\
6 & Total carbohydrate & $3 \mathrm{~g}$ & $1 \%$ \\
7 & Dietary fiber & $20 \mathrm{mg}$ & $3 \%$ \\
8 & Sugar & $125 \mathrm{mg}$ & $45 \%$ \\
9 & Sodium & & $10 \%$ \\
10 & Potassium & & $15 \%$ \\
\hline 11 & Vitamin A & & $0 \%$ \\
12 & Vitamin C & & $0 \%$ \\
13 & Vitamin E & & \\
14 & Calcium & & \\
15 & Iron & & \\
\hline
\end{tabular}

*Percent Daily Values based on 2000 calorie diet.

Pandan fruits from the middle mountainous area of Jayawijaya Papua have relatively great fat potency for future development. The function of fat in human body is to produce and store energy, to construct/form body structure, to protect from losing the body heat, to control body temperature, to save protein in the body, to dissolve vitamins A, D, E, K in the body [10] [11]. Both unsaturated and saturated fatty acids are essential ones derived from vegetables necessarily required by human body [12] [13] [14] [15].

Pandan's fleshy receptacle and seed contains and has very good protein to develop into various functional food products. Functional food is food-stuff containing active components which are important in human health [11] [16]. In the body, proteins perform as enzyme substance to control movements, immunity and important transporter [16] [17] [18] [19] [20].

Carbohydrates in fleshy receptacle are potential to develop into an alternative food-stuff replacing wheat flour made from oat and rice. Pandan fruits contains complete bioactive components such as minerals and vitamins necessarily required to reduce diabetes and cardiovascular risks. Consuming high carbohydrate food with less vitamins and minerals leads to high risk of diabetes and cardiovascular [21].

The dietary fiber in Pandan fleshy receptacle and seed is potential to develop in food and medicine processing industries. Its soluble properties are able to lessen cholesterol level in blood plasma by binding bile acid to increase feces volume [22]. The dietary fiber which absorbs bile acid and is discarded with faces is the cholesterol becoming basic material to produce gastric acid. The cholesterol triggers coronary heart diseaseone of the main causes in human death.

Starch from five species of Pandan is potential to develop into raw materials for producing bio-ethanol by fermentation method in the future. Through fermentation, ethanol is produced and it requires Sacharomyces cerevisiae yeast sugar with Zymonas mobilis bacteria which is able to accelerate ethanol fermentation [23]. Besides producing bio-ethanol, it produces raw materials for industries, pharmacies, drinks, cosmetics, and fuels. Developing bio-ethanol from Pandan as an alternative fuel is beneficial since it contribute to minimize global warming. Thus, Pandan forest will be developed as its native habitat without deforestation. This strategy will lead to the proper tropical forest conservation program in developing countries [1]. The highest production of Pandan fruits is obtained from forests instead of unproductive open lands.

Sodium is the main cation from extracellular liquid, osmotic concentration controlling, and body liquid volume. Its main function in the body as $\mathrm{HCl}$ formation is very significant for $\mathrm{Fe}$ absorption in stomach. Also, it helps irritability from muscular cells, buffer compound, or liquid restraint compound in the body. Losing Sodium from the body results in vomiting, diarrhea, and sweating [10]. Fruits from five types of Pandan have Sodium element necessary for the body.

Potassium element is very significant for body growth, muscle contraction, transmission of neural impulses, neural and muscular cells. Consuming Sodium bicarbonate for young athletes is significant as it can improve workout intensity and swimming between 50-200 meters for the distance composition [24]. In terminology, local residents of Papua hinterland consume Pandan fruits daily as their staple food so they have strong muscles which enable them to travel 100-200 kilometers for 10-15 hours on foot. Pandan fruits have high Sodium which are potential to be the food for athletes or other branches of sport.

Calcium functions in bone and tooth composition, blood coagulation, excitability of neural muscle, cellular fracture, transmissions of neural impulses, improving the function of cell membrane, activation of 
enzyme reaction, and hormone release [10] [11]. The potency within five types of Pandan fruits has nutritive value of high Calcium developed into food and medicine.

Among five types of Pandan, Vitamin A is only found in fleshy receptacle and seed of Pandanus sp.1 (owadak). The fleshy receptacle of Pandanus sp.1 (owadak) is orange to pink in color and contains high carotene as the source of vitamin A. It needs to be naturally developed for acquiring body health particularly for eyes. As far, the important of vitamin consuption is poor understood by local people. The education of nutrition to substitute vitamin A as regular food input containing rich source of carotene is necessarily required [25].

Consuming fruits, vegetables, and leaves containing rich and high vitamin $\mathrm{C}$ will result in health improvement of heart, reduced diabetes, cataract, and cancer [26] [27]. The fruit storage for two weeks in $50^{\circ} \mathrm{C}$ room temperature does not cause the loss of vitamin $C$ [28]. The fleshy receptacle and seed of five pandan species have vitamin $\mathrm{C}$ as an anti-oxidant which is crucial for future development. Vitamin $\mathrm{E}$ within the vegetable fatty acid has an important anti-oxidant to prevent bleeding in pregnant women and after childbirth [29]. It is detected in five types of Pandan and potential to be an anti-oxidant for future development.

\section{Conclusion}

The study confirmed that compositions of fat nutrition value per 100 grams in Pandanus julianettii's fleshy receptacle and seed were $0.67 \%$ and $47 \%$; those in Pandanus iwen were $0.43 \%$ and $50 \%$; those in Pandanus sp.1. (owadak) were $20.58 \%$ and $33.08 \%$; those in Pandanus sp.2 (woromo) were $1 \%$ and 48.67 ; those in Pandanus brosimos were $1.34 \%$ and $48.41 \%$. Compositions of protein nutrition value per 100 grams in Pandanus julianettii's fleshy receptacle and seed were $8 \%$ and $18 \%$; those in Pandanus sp.1 (owadak) were $7.29 \%$ and $10.41 \%$; those in Pandanus sp.2 (woromo) were $10 \%$ and $15.40 \%$; those in Pandanus iwen were 5.84\% and $15.08 \%$; those in Pandanus brosimos were $5.47 \%$ and $16.06 \%$. Compositions of carbohydrate nutrition value per 100 grams in Pandanus julianettii's pulp and seed were $77 \%$ and $28 \%$; those in Pandanus sp.1 (owadak) were $62.27 \%$ and $47.90 \%$; those in Pandanus sp.2 (woromo) were $74 \%$ and $25 \%$; those in Pandans iwen were $77.17 \%$; and $27.61 \%$; those in Pandanus brosimos were $77.45 \%$ and $20.06 \%$.

Compositions of Sodium nutrition value per 100 grams in Pandanus julianettii's fleshy receptacle and seed were $87.84 \mathrm{mg}$ and $71.21 \mathrm{mg}$; those in Pandanus sp.1. (owadak) were $25.86 \mathrm{mg}$ and $22.49 \mathrm{mg}$; those in Pandanus sp.2. (woromo) were $47.19 \mathrm{mg}$ and $77.58 \mathrm{mg}$; those in Pandanus iwen were $49.20 \mathrm{mg}$ and $56.25 \mathrm{mg}$; those in Pandanus brosimos were $73.96 \mathrm{mg}$ and $63.70 \mathrm{mg}$. Compositions of Calcium nutrition value in Pandanus julianettii's pulp and seed were $148.55 \mathrm{mg}$ and $97.20 \mathrm{mg}$; those in Pandanus sp.1. (owadak) were $18.31 \mathrm{mg}$ and $2.46 \mathrm{mg}$; those in Pandanus sp.2. (woromo) were $284.90 \mathrm{mg}$ dan $72.44 \mathrm{mg}$; those in Pandanus iwen were $127.00 \mathrm{mg}$ and $51.44 \mathrm{mg}$; those in Pandanus brosimos were $351.41 \mathrm{mg}$ and $92.95 \mathrm{mg}$. Compositions of vitamin A nutrition value per 100 grams in Pandanus julianettii's fleshy receptacle and seed were $0.02 \mathrm{IU} / \mathrm{g}$ and $0.02 \mathrm{IU} / \mathrm{g}$; those in Pandanus sp.1 (owadak) were $279.21 \mathrm{IU} / \mathrm{g}$ and $864.84 \mathrm{IU} / \mathrm{g}$; those in Pandanus sp.2. (woromo) were $0.30 \mathrm{IU} / \mathrm{g}$ and $0.02 \mathrm{IU} / \mathrm{g}$; those in Pandanus iwen were $0.02 \mathrm{IU} / \mathrm{g}$ and $0.02 \mathrm{IU} / \mathrm{g}$; those in Pandanus brosimos were $0.87 \mathrm{IU} / \mathrm{g}$ and $0.76 \mathrm{IU} / \mathrm{g}$.

\section{Acknowledgements}

We would like to thank Local Government of Lanny Jaya Regency, Director and Staff of Postgraduate Program, Faculty of Agriculture, University of Brawijaya, Head of Central Laboratory of Life Sciences, University of Brawijaya, Malang and Head of Biochem Laboratory in Surabaya for their support during the paper completion.

\section{References}

[1]. L. Hakim and M Miyakawa, Plant trees species for restoration program in Ranupani, Bromo Tengger Semeru National Park Indonesia. Biodiversity Journal. 4(3), 2013, 387-394.

[2]. DC. Hyndman, Ethnobotany of Wokaimin Pandanus: Significant Papua New Guinea plant resource, Economic Botany 3(38), 1984, 287-303.

[3]. M. Jebb, A fielf guide to pandanus in New Guinea, the Bismarrck Archipelago, the Solomon Island : 91 (Cristensen Research Institute, Madang1992).

[4]. S. Stone, Agronomic study of Karuka. Proposal and Scheme for an agronomic study of Pandanus julianettii and Pandanus brosimos, the karuka nut trees of Papua New Guinea (Department of primary Industry, Horticulture Sections, Port Moresby, Papua new Guinea, 1982).

[5]. S. Stone, Pandanus from Ok Tedi Region, Papua New Guinea, collected by Debra Donoghue. Economic Botany 38(3), 1984, 304313.

[6]. Y. Purwanto and E. Munawaroh, Etnobotani Jenis-jenis Pandanaceae Sebagai bahan Pangan di Indonesia. Pusat Penelitian Biologi LIPI Bogor. Edisi khus 5(A), 2010, 79-108.

[7]. J. Powel, Ethnobotany, In K. Pajimans (Ed.), New Guinea Vegetation (Australia National University Press, Camberra, 1976).

[8]. MW. Hamm and AC. Bellows, Community food security and nutrition educators, Journal of Nutrition Education and Behavior, $35(1), 2003,37-43$.

[9]. H. Godfray, JR. Beddington, IR. Crute, L. Haddad, D. Lawrence, JF. Muir, J. Pretty, S. Robinson, SM. Thomas and C. Toulmin, Food security: the challenge of feeding 9 billion people. Science, 327(5967), 2010, 812-818. 
[10]. G. Kartasapoetra and H. Marsetyo, Ilmu gizi (Korelasi gizi, kesehatan dan produktivitas kerja (Rineka Cipta, Jakarta, 2010).

[11]. S. Winarti, Makanan fungsional (Graha Ilmu Yogyakarta, 2010)

[12]. C. Leizer, D. Ribnicky., A. Poulev, S. Dushenkov and I. Raskin, The Composition of Hemp Seed Oil and Its Potential as an Important Source of Nutrition. Journal of Nutraceuticals, Functional \& Medical Foods 2 (4), 2000, 20-31.

[13]. AH. Kirsty, LC. Crosbie, GW. Horgan, GJ. Miller and AK. Dutta-Roy. Effect of diets rich in oleic acid, stearic acid and linoleic acid on postprandial haemostatic factors in young healthy men. British Journal of Nutrition, 86 (29), $2001,207-215$.

[14]. J. Hum, Health Effects of Palm Oil. International Food Research Journal 26(3), 2009: 16-203.

[15]. M. Jafari, M. Kadivar and SAH. Goli, Response surface-optimized synthesis of cis-9,trans-11-octadecadienoic acid through dehydration of castor oil. International Food Research Journal 20 (4) 2013, 1997-2003.

[16]. A. Aberoumand, Protein, Fat, Calories, Minerals, Phytic acid and Phenolic In Some Plant Foods Based Diet. International Food Research Journal, 28(3) 2011, 19-33.

[17]. T. Bourtoom, Edible protein films: properties enhancement. International Food Research Journal, 16(9), 2009, 1-9.

[18]. M. Gianfranco, P. Gianluca, C. Simonetta, A. Francesco and P. Pasquale. Analysis of food proteins and peptides by mass spectrometry-based techniques. Journal of Chromatography, 121(209), 2009, 7130-7142.

[19]. S. Ghufran, A. Umer, S. Asad and A. Rashida, Food Protein: Food Colour Interactions and its Application in Rapid Protein Assay (Department of Food Science \& Technology and Division of Food Research Institute of Chemistry, University of Karachi, Pakistan, 2010)

[20]. L. Yi, S. Bolca., S. Van de Vijvere., S. De Vriese, T. Mouratidou., M. De Neve., A. Polet., H. Van Oyen., J. Van Camp., G. De Backer., S. De Henauw and Inge Huybrechts. Animal and plant protein intake and its association with overweight and obesity among the Belgian population. British Journal of Nutrition 105(10), 2011, 1106-1116.

[21]. J. Mann, Dietary carbohydrate: relationship to cardiovascular disease and disorders of carbohydrate metabolism. European Journal of Clinical Nutrition, 61(1), 2007, 100-111.

[22]. J Mann, JH Cummings, HN Englyst, T Key, S Liu, G Riccardi, C Summerbell, R Uauy, RM van Dam, B Venn, HH Vorster and M Wiseman. FAO/WHO Scientific Update on carbohydrates in human nutrition: conclusions. European Journal of Clinical Nutrition, 61(1), 2007, 132-137.

[23]. L. Carlos, T. Olitta, and S. Nitsche, R. Ethanol Production in Brazil: The Industrial Process and Its Impact on Yeast Fermentation (Biofuel Production - Recent Developments and Prospects, Brazilia, 2011)

[24]. Z. Adam, C. Jaroslaw, P. Stanislaw, W. Zbigniew and L. Jozef Effects of sodium bicarbonate ingestion on swim performance in youth athletes. Journal of Sports Science and Medicine, 8 (2), 2009, 45-50.

[25]. S. Khan and SE. Mahmood Vitamin A deficiency among school Children of Bareilly. National Journal of Medical Research, 2(2), 2012, 2249-4995.

[26]. O. Ogunlesi, L. Azeez, V. Obakachi, M. Osunsanmi, and N. Kenchor, Vitamin C Contents of Tropical Vegetables and Foods Determined by Voltammetric and Titrimetric Methods and Their Relevance to the Medicinal Uses of the Plants. Journal of Food Composition and Analysis 19(26), 2010, 196-204.

[27]. D. Delia-Gabriela, M. Camelia, R. Diana-icoleta, and P. Mirela-Viorica, Vitamin C, chlorophylls, carotenoids and xanthophylls content in some basil (Ocimum basilicum L.) and rosemary (Rosmarinus officinalis L.) leaves extracts. Journal of Agroalimentary Processes and Technologies 18 (3), 2012, 253-258.

[28]. H. Yerena, L. Gloria and G. Mónica Determination of vitamin C in tropical fruits: a comparative evaluation of methods. Journal of Food Chemistry, 135(22), 2012, 150-154.

[29]. S. Paul, CM. Sally, H. Mary, U. Jay, K. Oda, LK. Jungvig, T. Wenli, JM. Suttorp, Di Valentine, R. Louis, S. Roberta and JN. Sydne, Effect of Supplemental Antioxidants Vitamin C, Vitamin E, and Coenzyme Q10 for the Prevention and Treatment of Cardiovascular Disease. Report/Technology Assessment, 83, 2013, 83-241. 